\title{
PENGARUH TINGKAT EFEKTIVITAS PERPUTARAN KAS, PIUTANG, DAN MODAL KERJA TERHADAP RENTABILITAS EKONOMI PADA KOPERASI PEDAGANG PASAR GROGOLAN BARU (KOPPASGOBA) PERIODE 2016-2020
}

\author{
Vivi Puji Astuti ${ }^{1}$, Yohani' ${ }^{2}$ Muh. Fithrayudi Triatmaja ${ }^{3}$ \\ 123 Program Studi Akuntansi Fakultas Ekonomika dan Bisnis Universitas \\ Muhammadiyah Pekajangan Pekalongan \\ Email : fithrayudi@gmail.com
}

\begin{abstract}
Abstrak
Penelitian ini bertujuan untuk menguji dan menganalisis pengaruh tingkat efektivitas dari perputaran kas, piutang, dan modal kerja terhadap rentabilitas ekonomi pada Koperasi Pedagang Pasar Grogolan Baru (KOPPASGOBA) Kota Pekalongan tahun 2016 sampai dengan tahun 2020. Metode yang digunakan dalam penelitian ini adalah metode penelitian kuantitatif dengan teknik dokumentasi dan dianalisis dengan menggunakan analisis regresi linier berganda. Hasil dari penelitian ini menunjukkan (1) tingkat efektivitas perputaran kas tidak berpengaruh signifikan terhadap rentabilitas ekonomi, (2) tingkat efektivitas perputaran piutang tidak berpengaruh signifikan terhadap rentabilitas ekonomi, (3) tingkat efektivitas perputaran modal kerja berpengaruh positif dan signifikan terhdap rentabilitas ekonomi, dan (4) terdapat pengaruh positif dan signifikan tingkat efektivitas perputaran kas, piutang, dan modal kerja secara bersama-sama terhadap rentabilitas ekonomi.
\end{abstract}

Kata Kunci: perputaran kas, perputaran piutang, perputaran modal kerja, dan rentabilitas ekonomi.

\section{THE EFFECT OF LEVEL EFFECTIVENESS OF CASH TURNOVER, RECEIVABLES, AND WORKING CAPITAL ON ECONOMIC RENTABILITY IN NEW GROGOLAN MARKET TRADERS COOPERATIVE PERIOD 2016-2020}

\footnotetext{
Abstract

This study aims to test and analyze the effect of effectiveness of cash turnover, receivables, and working capital on economic rentability in the New Grogolan Market Traders Cooperative of Pekalongan City from 2016 to 2020. The method used in this study was quantitative research method with documentation techniques and analyzed used multiple linear regression analysis. The results of this study showed (1) the effectiveness of cash turnover has no significant effect on economic rentability, (2) the effectiveness of receivables turnover has no significant effect on economic rentability, (3) the effectiveness of working capital turnover has a positive and significant effect on economic rentability, and (4) there is a positive and significant effect on the effectiveness of cash turnover, receivables, and working capital together on economic rentability.

Keywords: Turnover of cash, turnover of receivables, turnover of working capital, and economic rentability.
} 


\section{PENDAHULUAN}

Setiap negara yang berdaulat, upaya mensejahterakan rakyatnya harus mempunyai suatu identitas kebangsaan. Upaya peningkatan kesejahteraan umumnya dilakukan melalui upaya peningkatan pertumbuhan ekonomi sedangkan upaya untuk menjamin terpeliharanya identitas bangsa umumnya dilakukan melalui proses pembangunan. Pertumbuhan ekonomi dan pembangunan ekonomi merupakan suatu hal sangat sentral untuk dibicarakan karena hal tersebut berhadapan langsung dengan kesejahteraan masyarakat (Kementerian PPN/ Bappenas).

Saat ini hampir semua negara di dunia, sedang menghadapi tantangan berat yang tidak pernah terbayangkan sebelumnya. Pandemi Covid-19 tidak hanya membawa problematik kesehatan masyarakat saja, tetapi juga pada implikasi ekonomi yang sangat luas. Perlambatan pertumbuhan ekonomi dunia dan penurunan volume perdagangan menjadi koreksi tajam terhadap target pembangunan dan pertumbuhan ekonomi Indonesia (Kementerian PPN/ Bappenas).

Salah satu program pemulihan ekonomi sosial yang diharapkan Presiden Republik Indonesia, yaitu perkoperasian nasional. Secara umum koperasi merupakan organisasi yang didukung oleh pemerintah untuk meningkatkan kesejahteraan masyarakat melalui peningkatan pendapatan perkapita baik anggota maupun non anggota (Fajri 2016). Untuk mengukur keberhasilan koperasi dalam mewujudkan operasi koperasi yang efisien dalam membantu pemerintah mendongkrak pemulihan ekonomi nasional, tidak hanya dilihat dari besar kecilnya jumlah laba yang diperoleh koperasi itu sendiri, tetapi juga dilihat dari efektivitas pengelolaan koperasi.

Rentabilitas adalah kemampuan suatu koperasi untuk menghasilkan laba selama periode tertentu. Rentabilitas suatu koperasi dapat dinilai dari keberhasilan koperasi dan kemampuan menggunakan aktiva secara produktif (Riyanto 2001). Dwi Martani (2012) menyatakan bahwa kas adalah aset keuangan yang digunakan untuk kegiatan operasional koperasi. Uang kas yang tersedia tidak dipergunakan secara maksimal untuk kegiatan operasi koperasi, akan mengurangi tingkat laba yang diharapkan pada periode berjalan. Dengan mengetahui tingkat perputaran kas, dapat menunjukkan kondisi koperasi dalam pengelolan aktiva secara produktif atau non-produktif (Firman 2018, 8).

Selain kas, piutang juga merupakan bagian dari aktiva, yang keberadaanya akan selalu berputar, dalam arti piutang tersebut akan tertagih pada saat tertentu. Periode perputaran piutang tergantung pada panjang pendeknya ketentuan waktu yang dipersyaratkan dalam syarat pembayaran kredit. Dengan mengetahui tingkat perputaran piutang, dapat 
menunjukkan kondisi koperasi dalam pengelolan aktiva secara produktif atau non-produktif (Fahmi 2013, 155).

Sebagaimana bentuk koperasi lainnya, pengoperasian koperasi tidak dapat dipisahkan dari kebutuhan akan modal kerja. Modal kerja adalah aktiva lancar yang digunakan dalam kegiatan operasional dan selalu berputar dalam periode tertentu (Ibrahim 2011, 151). Perputaran modal kerja diharapkan dapat terjadi dalam waktu yang relatif pendek, sehingga modal yang ditanamkan dalam koperasi akan cepat kembali (Murtiningsih 2016, 6). Semakin besar rasio perputaran modal kerja, maka semakin tinggi pula tingkat efisiensi penggunaan modal kerja dan menunjukkan bahwa penggunan modal dapat dinyatakan produktif (Husnan 2004, 182).

Perkembangan dan kemajuan KOPPASGOBA dapat dilihat dari tingkat perkembangan efisiensi penggunaan modal kerja yang diharapkan perputaran modal kerja terjadi dalam waktu yang relatif pendek, sehingga modal yang ditanamkan dalam koperasi akan cepat kembali. Begitu pula dengan kas, manajemen perlu memperhatikan pengelolaan kas agar tidak terjadi adanya pengangguran uang kas yang berlebihan. Selain itu, dapat dilihat pula tingkat perkembangan perputaran dan periode terikatnya piutang. Jika perputaran piutang KOPPASGOBA Kota Pekalongan dari tahun ke tahun semakin cepat hal ini menunjukkan adanya tingkat efektivitas yang tinggi dalam pengelolaan keuangan KOPPASGOBA Kota Pekalongan dan sebaliknya jika perputaran piutangnya sangat lambat hal ini menunjukkan efektivitas yang rendah dalam KOPPASGOBA Kota Pekalongan.

Dari uraian di atas dan berdasarkan pengamatan peneliti pada Koperasi Pedagang Pasar Grogolan Baru (KOPPASGOBA) Kota Pekalongan, maka perumusan masalah dalam penelitian ini adalah (1) Apakah tingkat efektivitas perputaran kas berpengaruh signifikan terhadap rentabilitas ekonomi pada Koperasi Pedagang Pasar Grogolan Baru (KOPPASGOBA) Kota Pekalongan? (2) Apakah tingkat efektivitas perputaran piutang berpengaruh signifikan terhadap rentabilitas ekonomi pada Koperasi Pedagang Pasar Grogolan Baru (KOPPASGOBA) Kota Pekalongan? (3) Apakah tingkat efektivitas modal kerja berpengaruh signifikan terhadap rentabilitas ekonomi pada Koperasi Pedagang Pasar Grogolan Baru (KOPPASGOBA) Kota Pekalongan? (4) Apakah tingkat efektivitas perputaran kas, piutang, dan modal kerja secara simultan berpengaruh signifikan terhadap rentabilitas ekonomi pada Koperasi Pedagang Pasar Grogolan Baru (KOPPASGOBA) Kota Pekalongan? 
Tujuan dari penelitian ini adalah (1) Untuk menguji dan menganalisis pengaruh tingkat efektivitas perputaran kas terhadap rentabilitas ekonomi pada Koperasi Pedagang Pasar Grogolan Baru (KOPPASGOBA) Kota Pekalongan periode 2016-2020. (2) Untuk menguji dan menganalisis pengaruh tingkat efektivitas perputaran piutang terhadap rentabilitas ekonomi pada Koperasi Pedagang Pasar Grogolan Baru (KOPPASGOBA) Kota Pekalongan periode 2016-2020. (3) Untuk menguji dan menganalisis pengaruh tingkat efektivitas modal kerja terhadap rentabilitas ekonomi pada Koperasi Pedagang Pasar Grogolan Baru (KOPPASGOBA) Kota Pekalongan periode 2016-2020. (4) Untuk menguji dan menganalisis pengaruh tingkat efektivitas perputaran kas, piutang, dan modal kerja secara simultan terhadap rentabilitas ekonomi pada Koperasi Pedagang Pasar Grogolan Baru (KOPPASGOBA) Kota Pekalongan periode 2016-2020.

\section{LANDASAN TEORI DAN PENGEMBANGAN HIPOTESIS}

\subsection{Rentabilitas Ekonomi}

Rentabilitas ekonomi adalah perbandingan antara laba usaha dengan total aktiva yang digunakan untuk menghasilkan laba tersebut dan dinyatakan dalam persentase (Riyanto, 2012:228). Rentabilitas seringkali digunakan untuk mengukur efesiensi penggunaan aktiva dalam suatu koperasi. Maka, rentabilitas ekonomi sering pula dimaksudkan sebagai kemampuan suatu koperasi dengan seluruh aktiva yang bekerja didalamnya untuk menghasilkan laba. Rumus untuk menghitung rentabilitas ekonomi suatu koperasi dalam Peraturan Deputi Bidang Pengawasan Kementerian Koperasi dan Usaha Kecil dan Menengah Republik Indonesia No: 06/Per/Dep.6/IV/2016 diuraikan sebagai berikut:

$$
\text { R.E }=\frac{\text { Laba sebelum pajak }}{\text { Total Aktiva }} \times 100 \%
$$

Berikut adalah Standar Penilaian Rasio Rentabilitas Peraturan Menteri Negara Koperasi dan Usaha Kecil dan Menengah Republik Indonesia No. 06/Per/M.KUKM/V/2006:

Tabel 2.1 Standar Penilaian Rasio Rentabilitas

\begin{tabular}{|c|c|l|}
\hline \multirow{4}{*}{$\begin{array}{c}\text { Rentabilitas Return } \\
\text { On Investment }\end{array}$} & Kriteria & \multicolumn{1}{|c|}{ Keterangan } \\
\cline { 2 - 3 } & $>10 \%$ & Sangat Baik \\
\cline { 2 - 3 } & $3 \%-10 \%$ & Baik \\
\cline { 2 - 3 } & $1 \%-7 \%$ & Cukup Baik \\
\cline { 2 - 3 } & $1 \%-3 \%$ & Kurang Baik \\
\hline
\end{tabular}




\subsection{Perputaran Kas}

Perputaran kas merupakan periode berputarnya kas yang dimulai pada saat kas diinvestasikan dalam komponen modal kerja sampai saat kembali menjadi kas sebagai unsur modal kerja yang paling tinggi likuiditasnya (Menuh 2008). Rasio perputaran kas berfungsi untuk mengukur tingkat kecukupan modal kerja koperasi yang dibutuhkan untuk membayar tagihan dan membiayai penjualan (Kasmir 2013). Rumus yang digunakan untuk mencari rasio perputaran kas menurut Kasmir (2013), sebagai berikut:

$$
\begin{gathered}
\text { Perputaran kas }=\underset{\text { Kas rata-rata }}{\text { X 100\% }} \\
\text { Kalan Bersih }
\end{gathered}
$$

Dalam koperasi, untuk menilai rasio efektivitas perputaran kas yaitu dengan menggunakan kriteria standar rasio efektivitas perputaran kas (Pedoman Penilaian Koperasi Peraturan Menteri Negara Koperasi dan Usaha Kecil dan Menengah Republik Indonesia No. 06/Per/M.K UKM/V/2006), sebagai berikut:

Tabel 2.2 Standar Rasio Efektivitas Perputaran Kas

\begin{tabular}{|c|c|c|}
\hline \multirow{6}{*}{$\begin{array}{c}\text { Standar Rasio } \\
\text { Efektivitas } \\
\text { Perputaran } \\
\text { Kas }\end{array}$} & Kriteria & Keterangan \\
\hline & $>3,5$ kali & Sangat Efektif \\
\hline & 2,5 - 3,5 Kali & Efektif \\
\hline & 1,5 - 2,5 Kali & Cukup Efektif \\
\hline & $1-<1,5$ Kali & Kurang Efektif \\
\hline & $<1$ Kali & Tidak Efektif \\
\hline
\end{tabular}

\subsection{Perputaran Piutang}

Martono dan Harjito (2003) menyatakan bahwa perputaran piutang adalah periode terikatnya piutang sejak terjadinya piutang sampai piutang tersebut dapat ditagih dalam bentuk uang kas dan akhirnya dapat dibelikan kembali menjadi persediaan dan dijual secara kredit menjadi piutang kembali. Semakin fleksibel atau semakin lama syarat pembayarannya maka semakin lama modal terikat pada piutang, yang berarti bahwa tingkat perputarannya selama periode tertentu adalah semakin rendah. Rasio perputaran piutang merupakan tolak ukur yang menunjukkan seberapa besar berputarnya piutang dalam periode tertentu. Rumus yang digunakan untuk mengetahui rasio perputaran piutang, dalam Kasmir (2016) diuraikan sebagai berikut:

$$
\text { Perputaran Piutang }=\frac{\text { Penjualan Bersih }}{\text { Piutang rata-rata }} \times 100 \%
$$


Dalam koperasi, untuk menilai rasio perputaran piutang yaitu dengan menggunakan kriteria standar rasio efektivitas perputaran piutang (Pedoman Penilaian Koperasi Peraturan Menteri Negara Koperasi dan Usaha Kecil dan Menengah Republik Indonesia No. 06/Per/M.K UKM/V/2006), sebagai berikut:

Tabel 2.3 Standar Rasio Efektivitas Perputaran Piutang

\begin{tabular}{|c|c|l|}
\hline \multirow{4}{*}{$\begin{array}{c}\text { Standar Rasio } \\
\text { Efektivitas }\end{array}$} & Kriteria & \multicolumn{1}{|c|}{ Keterangan } \\
\cline { 2 - 3 } Perputaran Piutang & $>12 \mathrm{Kali}$ & Sangat Efektif \\
\cline { 2 - 3 } & $10-12 \mathrm{Kali}$ & Efektif \\
\cline { 2 - 3 } & $8-10 \mathrm{Kali}$ & Cukup Efektif \\
\cline { 2 - 3 } & $6-8 \mathrm{Kali}$ & Kurang Efektif \\
\cline { 2 - 3 } & $<6 \mathrm{Kali}$ & Buruk \\
\hline
\end{tabular}

\subsection{Perputaran Modal Kerja}

Santoso (2013) mengemukakan bahwa perputaran modal kerja atau working capital turnover adalah suatu rasio yang digunakan dalam mengukur keefektifan modal kerja koperasi selama periode tertentu. Dari hasil perhitungan apabila perputaran modal kerja rendah berarti pengelolaan modal kerja belum efektif dan sebaliknya apabila perputaran modal kerja tinggi berarti modal kerja perusaahan telah efektif, Kasmir (2011). Kasmir (2016) menguraikan rumus yang digunakan untuk mengetahui rasio perputaran modal kerja adalah sebagai berikut:

$$
\text { Perputaran Modal Kerja }=\frac{\text { Penjualan bersih }}{\text { Modal kerja rata-rata }} \times 100 \%
$$

Dalam koperasi, untuk menilai rasio perputaran modal kerja yaitu dengan menggunakan kriteria standar rasio efektivitas perputaran modal kerja (Standar Penilaian Koperasi SK Menteri No. 129/Kep/M/K. UKM/XI/2002), sebagai berikut:

Tabel 2.4 Standar Rasio Efektivitas Perputaran Modal Kerja

\begin{tabular}{|c|c|l|}
\hline \multirow{2}{*}{ Standar Rasio } & Kriteria & \multicolumn{1}{|c|}{ Keterangan } \\
\cline { 2 - 3 } Efektivitas & $>3 \mathrm{kali}$ & Sangat Efektif \\
\cline { 2 - 3 } Perputaran & $3-2 \mathrm{Kali}$ & Efektif \\
\cline { 2 - 3 } Modal Kerja & $1-0 \mathrm{Kali}$ & Cukup Efektif \\
\cline { 2 - 3 } & $<0 \mathrm{Kali}$ & Kurang Efektif \\
\hline
\end{tabular}




\subsection{Kerangka Pemikiran Teoritis}

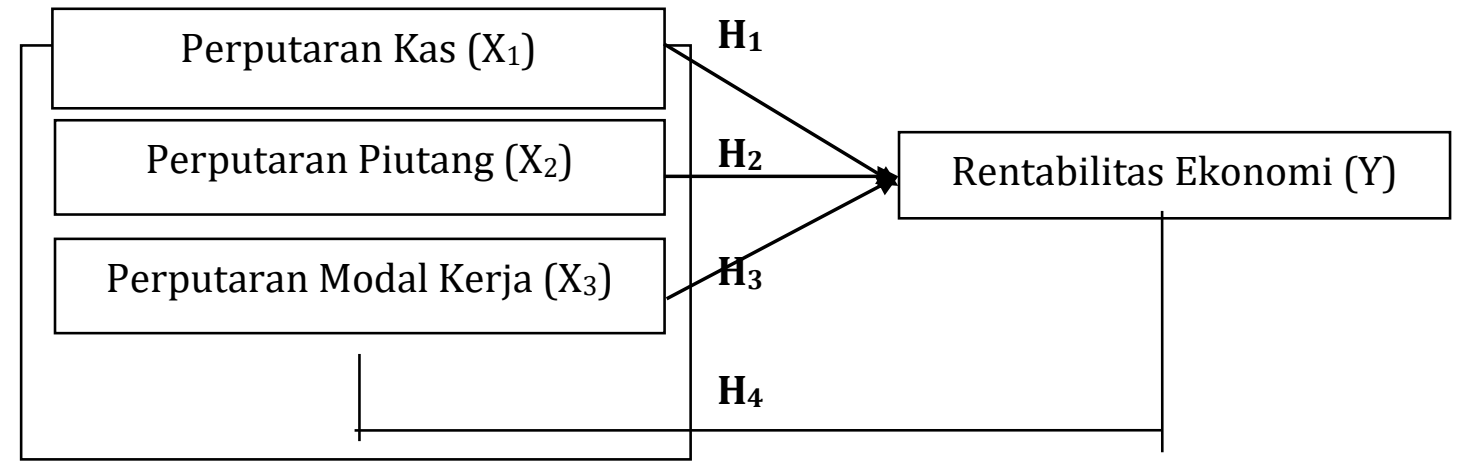

Gambar 2.1 Kerangka Pemikiran Teoritis

Sumber: Konsep diolah, 2021

\subsection{Hipotesis}

$\mathrm{H}_{1}$ : Perputaran Kas berpengaruh positif dan signifikan terhadap rentabilitas ekonomi

$\mathrm{H}_{2}$ : Perputaran Piutang berpengaruh positif dan signifikan terhadap rentabilitas ekonomi

$\mathrm{H}_{3}$ : Perputaran Modal Kerja berpengaruh positif dan signifikan terhadap rentabilitas ekonomi

$\mathrm{H}_{4}$ : Perputaran Kas, Piutang, dan Modal Kerja berpengaruh positif dan signifikan terhadap rentabilitas ekonomi

\section{METODE PENELITIAN}

\subsection{Jenis Penelitian}

Jenis data yang digunakan dalam penelitian ini adalah data sekunder yang telah tersedia dari subjek penelitian dan diperoleh secara langsung melalui dokumentasi dan wawancara.

\subsection{Subjek Penelitian}

Data diperoleh dari Laporan Buku Setoran Bulanan dan Laporan Tutup Buku Tahunan Koperasi Pedagang Pasar Grogolan Baru (KOPPASGOBA) Kota Pekalongan periode 2016 sampai dengan 2020 yang telah di audit. Dimana sampel yang digunakan sebanyak 60 sampel data pengamatan yang dianalis, yang mana berasal dari data per bulan dikali periode tahun yang diteliti (12 Bulan x 5 Tahun $=60$ Data).

\subsection{Teknik Pengumpulan Data}

Sumber data sekunder ini diperoleh langsung dari Koperasi Pedagang Pasar Grogolan Baru (KOPPASGOBA) Kota Pekalongan yang berupa file dan dokumentasi dengan melakukan tinjauan langsung pada dokumen yang relevan untuk mendasari pembahasan guna mendukung keberhasilan penelitian ini.

\subsection{Teknik Analisis Data}

Teknik analisis yang digunakan dalam penelitian ini adalah metode analisis regresi linier berganda untuk mengetahui hubungan yang signifikan dari tiga variabel independen dan satu variabel 
dependen. Persamaan regresi berganda dalam penelitian ini adalah sebagai berikut :

$$
\begin{aligned}
& \text { Dimana: } \quad Y=a+b_{1} \cdot E p k+b_{2} \cdot E p p+b_{3} \cdot E m k+e \\
& \text { Y : Rentabilitas Ekonomi } \\
& \text { a : Konstanta } \\
& \text { b1 : Koefisien regresi untuk X1 } \\
& \text { b2 : Koefisien regresi untuk X2 } \\
& \text { b3 : Koefisien regresi untuk X3 } \\
& \text { Epk : Efektivitas Perputaran Kas } \\
& \text { Epp : Efektivitas Perputaran Piutang } \\
& \text { Emk : Efektivitas Perputaran Modal Kerja }
\end{aligned}
$$

3.4.1. Koefisien determinasi $\left(\mathrm{R}^{2}\right)$

$\mathrm{R}^{2}$ bertujuan untuk mengukur seberapa jauh kemampuan model dalam menerangkan variasi variabel dependen.

3.4.2. Pengujian Hipotesis

3.4.2.1. Uji Parsial (Uji-t)

Uji hipotesis secara parsial (Uji-t) digunakan untuk menunjukkan seberapa jauh pengaruh satu variabel independen terhadap variabel dependen.

3.4.2.2. Uji Simultan (Uji-F)

Uji hipotesis secara simultan (Uji-F) digunakan untuk menunjukkan apakah semua variabel independen yang dimasukan dalam model mempunyai pengaruh secara bersama-sama terhadap variabel dependen.

\section{HASIL DAN PEMBAHASAN}

\subsection{Hasil Penelitian}

4.2.

Tabel 4.1 Hasil Uji Statistik Deskriptif Descriptive Statistics

\begin{tabular}{|l|r|r|r|r|r|}
\hline & Minimum & Maximum & Mean & Std. Deviation & $\mathrm{N}$ \\
\hline Rentabilitas Ekonomi & .07 & .53 & .3330 & .09271 & 60 \\
Perputaran Kas & .75 & 8.68 & 3.3107 & 1.96732 & 60 \\
Perputaran Piutang & .09 & 0.63 & .4192 & .10591 & 60 \\
Perputaran Modal Kerja & .07 & .46 & .2888 & .07517 & 60 \\
\hline
\end{tabular}

Berdasarkan hasil uji statistik deskriptif dalam penelitian ini, dapat dijelaskan sebagai berikut:

4.2.1. Nilai minimum rentabilitas ekonomi adalah sebesar 0,07 dan nilai maksimum sebesar 0,53 serta rata-rata sebesar 0,33. Laporan bulanan Koperasi Pedagang Pasar Grogolan Baru (KOPPASGOBA) Kota Pekalongan yang memiliki nilai rasio rentabilitas ekonomi terendah terdapat pada bulan juni tahun 2018. Laporan bulanan Koperasi Pedagang Pasar Grogolan Baru (KOPPASGOBA) Kota Pekalongan yang memiliki nilai 
rasio rentabilitas ekonomi tertinggi terdapat pada bulan juli 2018. Deviasi standar untuk rentabilitas ekonomi adalah 0,09 . Hal ini berarti terjadi penyimpangan nilai rentabilitas ekonomi terhadap nilai rata-ratanya sebesar 0,09 .

4.2.2. Nilai minimum perputaran kas adalah sebesar 0,75 dan nilai maksimum sebesar 8,68 serta rata-rata sebesar 3,31. Laporan bulanan Koperasi Pedagang Pasar Grogolan Baru (KOPPASGOBA) Kota Pekalongan yang memiliki nilai rasio perputaran kas terendah terdapat pada bulan november tahun 2020. Laporan bulanan Koperasi Pedagang Pasar Grogolan Baru (KOPPASGOBA) Kota Pekalongan yang memiliki nilai rasio perputaran kas tertinggi terdapat pada bulan juni 2018. Deviasi standar untuk perputaran kas adalah 1,97. Hal ini berarti terjadi penyimpangan nilai perputaran kas terhadap nilai rata-ratanya sebesar 1,97 .

4.2.3. Nilai minimum perputaran piutang adalah sebesar 0,09 dan nilai maksimum sebesar 0,63 serta rata-rata sebesar 0,42. Laporan bulanan Koperasi Pedagang Pasar Grogolan Baru (KOPPASGOBA) Kota Pekalongan yang memiliki nilai rasio perputaran piutang terendah terdapat pada bulan juni tahun 2018. Laporan bulanan Koperasi Pedagang Pasar Grogolan Baru (KOPPASGOBA) Kota Pekalongan yang memiliki nilai rasio perputaran piutang tertinggi terdapat pada bulan juli 2018. Deviasi standar untuk perputaran piutang adalah 0,10. Hal ini berarti terjadi penyimpangan nilai perputaran piutang terhadap nilai rata-ratanya sebesar 0,10 .

4.2.4. Nilai minimum perputaran modal kerja adalah sebesar 0,07 dan nilai maksimum sebesar 0,46 serta rata-rata sebesar 0,29. Laporan bulanan Koperasi Pedagang Pasar Grogolan Baru (KOPPASGOBA) Kota Pekalongan yang memiliki nilai rasio perputaran modal kerja terendah terdapat pada bulan juni tahun 2018. Laporan bulanan Koperasi Pedagang Pasar Grogolan Baru (KOPPASGOBA) Kota Pekalongan yang memiliki nilai rasio perputaran modal kerja tertinggi terdapat pada bulan juli 2018. Deviasi standar untuk perputaran modal kerja adalah 0,07 . Hal ini berarti terjadi penyimpangan nilai perputaran modal kerja terhadap nilai rata-ratanya sebesar 0,07 . 
4.3. Hasil Regresi Linier Berganda

Tabel 4.2 Hasil Regresi Linier Berganda

Coefficients $^{a}$

\begin{tabular}{|c|c|c|c|c|c|c|c|c|}
\hline & & \multicolumn{2}{|c|}{$\begin{array}{c}\text { Unstandardized } \\
\text { Coefficients }\end{array}$} & \multirow{2}{*}{\begin{tabular}{|c|}
$\begin{array}{c}\text { Standardized } \\
\text { Coefficients }\end{array}$ \\
Beta \\
\end{tabular}} & \multirow[b]{2}{*}{$t$} & \multirow[b]{2}{*}{ Sig. } & \multicolumn{2}{|c|}{$\begin{array}{c}\text { Collinearity } \\
\text { Statistics }\end{array}$} \\
\hline \multicolumn{2}{|c|}{ Model } & B & Std. Error & & & & Tolerance & VIF \\
\hline & (Constant) & -.006 & .017 & & -.373 & .711 & & \\
\hline & Perputaran Kas & .000 & .003 & -.015 & -.288 & .774 & .470 & 2.128 \\
\hline & Perputaran Piutang & .038 & .158 & .044 & .242 & .810 & .111 & 9.016 \\
\hline & Perputaran Modal Kerja & 1.128 & .226 & .915 & 4.997 & .000 & .102 & 9.775 \\
\hline
\end{tabular}

a. Dependent Variable: Rentabilitas Ekonomi

Berdasarkan tabel diatas dapat, maka persamaan regresinya adalah, sebagai berikut:

$$
Y=-0,006+0,000 \mathrm{Epk}+0,038 \mathrm{Epp}+1,128 \mathrm{Emk}+\mathrm{e}
$$

Dalam model persamaan regresi linier berganda di atas, dapat di interprestasikan sebagai berikut:

4.3.1. Konstanta (a) sebesar $-0,006$ artinya, apabila perputaran kas, piutang, dan modal kerja bernilai 0 maka rentabilitas ekonomi sebesar -0,006.

4.3.2. Koefisien Perputaran Kas $\left(X_{1}\right)$ sebesar 0,000 dan betanda positif, ini menunjukkan bahwa perputaran kas mempunyai hubungan yang searah dengan rentabilitas ekonomi. Hal ini mengandung arti bahwa setiap kenaikan perputaran kas satu satuan maka rentabilitas ekonomi akan naik sebesar 0,000 dengan asumsi bahwa variabel bebas yang lain dari model regresi adalah tetap atau konstan.

4.3.3. Koefisien Perputaran Piutang $\left(\mathrm{X}_{2}\right)$ sebesar 0,038 dan betanda positif, ini menunjukkan bahwa perputaran piutang mempunyai hubungan yang searah dengan rentabilitas ekonomi. Hal ini mengandung arti bahwa setiap kenaikan perputaran piutang satu satuan maka rentabilitas ekonomi akan naik sebesar 0,038 dengan asumsi bahwa variabel bebas yang lain dari model regresi adalah tetap atau konstan.

4.3.4. Koefisien Perputaran Modal Kerja $\left(X_{3}\right)$ sebesar 1,128 dan betanda positif, ini menunjukkan bahwa perputaran modal kerja mempunyai hubungan yang searah dengan rentabilitas ekonomi. Hal ini mengandung arti bahwa setiap kenaikan perputaran modal kerja satu satuan maka rentabilitas ekonomi akan naik sebesar 1,128 dengan asumsi bahwa variabel bebas yang lain dari model regresi adalah tetap atau konstan. 


\subsection{Hasil Analisis Koefisien Determinasi $\left(\mathbf{R}^{2}\right)$}

Tabel 4.3 Koefisien Determinasi $\left(\mathbf{R}^{2}\right)$

Model Summary ${ }^{\mathrm{b}}$

\begin{tabular}{|l|r|r|r|r|r|}
\hline Model & $\mathrm{R}$ & R Square & \multicolumn{1}{|c|}{$\begin{array}{c}\text { Adjusted R } \\
\text { Square }\end{array}$} & $\begin{array}{c}\text { Std. Error of the } \\
\text { Estimate }\end{array}$ & Durbin-Watson \\
\hline 1 & $.954^{\mathrm{a}}$ & .910 & .905 & .02854 & 1.957 \\
\hline
\end{tabular}

a. Predictors: (Constant), Perputaran Modal Kerja, Perputaran Kas, Perputaran Piutang

b. Dependent Variable: Rentabilitas Ekonomi

Tabel menunjukkan anka Adjusted R Square $\left(\mathrm{R}^{2}\right)$ sebesar 0,910 atau 91\%. Hal ini menunjukkan bahwa prosentase sumbangan pengaruh variabel independen (perputaran kas, piutang, dan modal kerja) terhadap variabel dependen (rentabilitas ekonomi) sebesar 91\%. Sedangkan sisanya sebesar 9\% dipengaruhi atau dijelaskan oleh variabel lain yang tidak dimasukkan dalam model penelitian ini.

\subsection{Hasil Analisis Uji Parsial (Uji-t)}

Tabel 4.4 Uji Parsial (Uji-t)

Coefficients $^{a}$

\begin{tabular}{|c|c|c|c|c|c|c|c|}
\hline \multirow[b]{2}{*}{ Model } & \multicolumn{2}{|c|}{$\begin{array}{l}\text { Unstandardized } \\
\text { Coefficients }\end{array}$} & \multirow{2}{*}{$\begin{array}{c}\begin{array}{c}\text { Standardized } \\
\text { Coefficients }\end{array} \\
\text { Beta }\end{array}$} & \multirow[b]{2}{*}{$\mathrm{T}$} & \multirow[b]{2}{*}{ Sig. } & \multicolumn{2}{|c|}{$\begin{array}{l}\text { Collinearity } \\
\text { Statistics }\end{array}$} \\
\hline & B & Std. Error & & & & Tolerance & VIF \\
\hline $1 \quad$ (Constant) & -.006 & .017 & & -.373 & .711 & & \\
\hline Perputaran Kas & .000 & .003 & -.015 & -.288 & .774 & .470 & 2.128 \\
\hline Perputaran Piutang & .038 & .158 & .044 & .242 & .810 & .111 & 9.016 \\
\hline Perputaran Modal Kerja & 1.128 & .226 & .915 & 4.997 & .000 & .102 & 9.775 \\
\hline
\end{tabular}

a. Dependent Variable: Rentabilitas Ekonomi

Terlihat pada Tabel menunjukkan bahwa Perputaran Kas $\left(\mathrm{X}_{1}\right)$ secara parsial tidak berpengaruh signifikan terhadap rentabilitas ekonomi karena nilai $t_{\text {hitung }} \leq t_{\text {tabel }}=-0,288 \leq 2,003\left(\mathrm{H}_{0}\right.$ diterima dan $\mathrm{H}_{1}$ ditolak). Perputaran Piutang $\left(\mathrm{X}_{2}\right)$ secara parsial tidak berpengaruh signifikan terhadap rentabilitas ekonomi karena nilai $t_{\text {hitung }} \leq t_{\text {tabel }}=$ $0,242 \leq 2,003\left(\mathrm{H}_{0}\right.$ diterima dan $\mathrm{H}_{2}$ ditolak). Perputaran Modal Kerja $\left(\mathrm{X}_{3}\right)$ secara parsial berpengaruh signifikan terhadap rentabilitas ekonomi karena nilai $t_{\text {hitung }} \geq t_{\text {tabel }}=4,997 \geq 2,003\left(\mathrm{H}_{0}\right.$ ditolak dan $\mathrm{H}_{3}$ diterima).

\subsection{Hasil Analisis Uji Simultan (Uji-F)}

\section{Tabel 4.5 Uji Simultan (Uji-F)}

ANOVA $^{\mathrm{b}}$

\begin{tabular}{|ll|r|r|r|r|r|}
\hline Model & & Sum of Squares & Df & Mean Square & F & Sig. \\
\hline 1 & Regression & .461 & 3 & .154 & 188.906 & $.000^{\mathrm{a}}$ \\
& Residual & .046 & 56 & .001 & & \\
& Total & .507 & 59 & & & \\
\hline
\end{tabular}

a. Predictors: (Constant), Perputaran Modal Kerja, Perputaran Kas, Perputaran Piutang

b. Dependent Variable: Rentabilitas Ekonomi 
Tabel menunjukkan bahwa secara simultan (bersama-sama) perputaran kas, piutang dan modal kerja berpengaruh signifikan terhadap rentabilitas ekonomi karena nilai $F_{\text {hitung }} \geq F_{\text {tabel }}=4188,906 \geq$ 2,77 $\left(\mathrm{H}_{0}\right.$ ditolak dan $\mathrm{H}_{\alpha}$ diterima).

\subsection{Pembahasan}

Hasil penelitian dengan uji statistik, variabel perputaran kas $\left(\mathrm{X}_{1}\right)$ tidak berpengaruh signifikan terhadap rentabilitas ekonomi. Dibuktikan dengan nilai nilai $t_{\text {hitung }}$ sebesar -0,288 dan $t_{\text {tabel }}$ sebesar 2,003 menandakan bahwa $t_{\text {hitung }} \leq t_{\text {tabel }}$ dengan nilai signifikan 0,774 > 0,05 maka hipotesis ditolak. Pada laporan keuangan Koperasi Pedagang Pasar Grogolan Baru (KOPPASGOBA) Kota Pekalongan selama tahun 2016 sampai dengan tahun 2020, jumlah kas yang dipertahankan kurang dari 5\% - 10\% dari jumlah aset yang dimiliki, sehingga kas kurang berperan penting dalam pencapaian laba koperasi yang menyebabkan rentabilitas ekonomi tidak terpengaruhi. Hasil ini sejalan dengan penelitian yang dilakukan oleh Dian Efriyenti (2018) dengan judul "Pengaruh Perputaran Kas, Perputaran Piutang, dan Perputaran Modal Kerja Terhadap Rentabilitas pada PT Pelayaran Sinar Mandiri Sejahtera Kota Batam" yang menyimpulkan bahwa perputaran kas secara parsial tidak berpengaruh terhadap rentabilitas.

Perputaran piutang $\left(\mathrm{X}_{2}\right)$ tidak berpengaruh signifikan terhadap rentabilitas ekonomi. Dibuktikan dengan nilai nilai thitung sebesar 0,242 dan $t_{\text {tabel }}$ sebesar 2,003 menandakan bahwa $t_{\text {hitung }} \leq t_{\text {tabel }}$ dengan nilai signifikan 0,810 >0,05 maka hipotesis ditolak. Pada laporan keuangan Koperasi Pedagang Pasar Grogolan Baru (KOPPASGOBA) Kota Pekalongan selama tahun 2016 sampai dengan tahun 2020, jumlah piutang dan penyisihan piutang tak tertagih semakin meningkat. Hal ini menyebabkan perputaran piutang semakin rendah yang menandakan bahwa semakin lamanya piutang untuk dapat tertagih (kredit macet) sehingga piutang kurang berperan dalam pencapaian laba koperasi. Hasil ini sejalan dengan penelitian yang dilakukan oleh Mardiansyah Nurcahya Gunawan (2019) dengan judul "Pengaruh Tingkat Perputaran Kas, Perputaran Persediaan, Perputaran Modal Kerja Terhadap Rentabilitas Ekonomi" yang menyimpulkan bahwa perputaran piutang tidak berpengaruh signifikan terhadap rentabilitas ekonomi.

Perputaran modal kerja $\left(\mathrm{X}_{2}\right)$ berpengaruh signifikan terhadap rentabilitas ekonomi. Dibuktikan dengan nilai nilai $t_{\text {hitung }}$ sebesar 4,997 dan $t_{\text {tabel }}$ sebesar 2,003 menandakan bahwa $t_{\text {hitung }} \leq t_{\text {tabel }}$ dengan nilai signifikan 0,000 < 0,05 maka hipotesis diterima. Pada laporan keuangan Koperasi Pedagang Pasar Grogolan Baru (KOPPASGOBA) Kota Pekalongan, menunjukkan apabila perputaran modal kerja 
mengalami kenaikan maka rentabilitas ekonomi akan naik, sebaliknya apabila perputaran modal kerja menurun maka rentabilitas ekonomi akan turun. Hasil ini sejalan dengan penelitian yang dilakukan oleh Anak Agung Ayu Mas Wasundari dan $\mathrm{Ni}$ Nyoman Suriani (2021) dengan judul "Pengaruh Perputaran Modal Kerja, Perputaran Piutang, dan Perputaran Persediaan Terhadap Rentabilitas Ekonomi Perusahaan Sektor Perdagangan Eceran di Bursa Efek Indonesia" yang menyimpulkan bahwa terdapat pengaruh signifikan antara perputaran modal kerja terhadap rentabilitas ekonomi.

Hasil penelitian dengan uji kuantitatif dapat dianalisa bahwa secara simultan dari ketiga variabel independen yang diteliti yaitu perputaran kas, perputaran piutang dan perputaran modal kerja pada Koperasi Pedagang Pasar Grogolan Baru (KOPPASGOBA) periode 2016-2020 memiliki pengaruh signifikan terhadap rentabilitas ekonomi. Dibuktikan dengan $F_{h i t u n g}$ sebesar 4188,906 dan $F_{h i t u n g}$ sebesar 2,77 menandakan bahwa $F_{\text {hitung }} \geq F_{\text {tabel }}$ dengan nilai signifikan $0,000<0,05$ maka hipotesis diterima. Pada laporan keuangan Koperasi Pedagang Pasar Grogolan Baru (KOPPASGOBA) Kota Pekalongan menunjukkan semakin tinggi perputaran kas, piutang, dan modal kerja secara bersama-sama maka semakin meningkat pula rentabilitas ekonomi. Sebaliknya, semakin rendah perputaran kas, piutang, dan modal kerja secara bersama-sama maka semakin turun pula rentabilitas ekonominya. Hasil ini sejalan dengan penelitian yang dilakukan oleh Anggun Tri Utami (2020) dengan judul "Pengaruh Perputaran Kas dan Perputaran Piutang Terhadap Rentabilitas Ekonomi pada Koperasi Finance di Bursa Efek Indonesia" yang menyatakan bahwa perputaran kas dan piutang secara simultan berpengaruh terhadap rentabilitas ekonomi.

\section{SIMPULAN DAN SARAN}

\subsection{Simpulan}

5.1.1. Perputaran kas secara parsial tidak berpengaruh terhadap rentabilitas ekonomi. Hal ini dikarenakan jumlah kas yang dipertahankan kurang dari 5\% - 10\% dari jumlah aset yang dimiliki, sehingga kas kurang berperan penting dalam pencapaian laba koperasi yang menyebabkan rentabilitas ekonomi tidak terpengaruhi.

5.1.2. Perputaran piutang secara parsial tidak berpengaruh terhadap rentabilitas ekonomi. Hal ini dikarenakan rendahnya perputaran piutang yang menandakan bahwa lamanya piutang untuk dapat tertagih (kredit macet) sehingga piutang kurang berperan dalam pencapaian laba koperasi.

5.1.3. Perputaran modal kerja secara parsial berpengaruh positif dan signifikan terhadap rentabilitas ekonomi. Hal ini dikarenakan 
modal kerja dalam koperasi digunakan dalam operasional secara baik sehingga dapat meningkatkan rentabilitas ekonomi.

5.1.4. Perputaran kas, piutang, dan modal kerja secara simultan berpengaruh positif dan signifikan terhadap rentabilitas ekonomi. Hal ini dikarenakan pengelolaan aktiva secara keseluruhan dengan baik, secara tidak langsung membawa koperasi kedalam kondisi yang menguntungkan sehingga dapat meningkatkan rentabilitas ekonomi.

5.2. Saran

5.2.1. Rasio keuangan yang mempengaruhi rentabilitas ekonomi dalam penelitian ini hanya terdiri dari tiga variabel, yaitu perputaran kas, perputaran piutang, dan perputaran modal kerja. Sedangkan masih banyak raiso keuangan lain yang mempengaruhi rentabilitas ekonomi, seperti perputaran persediaan, efisiensi modal kerja, efektivitas pengelolaan hutang, likuiditas, solvabilitas, size, dan lain sebagainya.

5.2.2. Sampel penelitian ini terbatas pada satu subyek saja yaitu Koperasi Pedagang Pasar Grogolan Baru (KOPPASGOBA) Kota Pekalongan. Diharapkan peneliti selanjutnya dapat memperluas sampel yang tidak hanya di Kota Pekalongan namun seluruh daerah Jawa Tengah ataupun daerah-daerah lain di Indonesia.

5.2.3. Diharapkan Koperasi Pedagang Pasar Grogolan Baru (KOPPASGOBA) Kota Pekalongan dapat mengelola modal kerja dengan baik agar kegiatan operasional koperasi-pun akan berjalan dengan baik dan secara tidak langsung membawa koperasi kedalam kondisi yang menguntungkan. Sehingga keberhasilan koperasi dan kemampuan koperasi dalam menggunakan aset dapat secara produktif serta meningkatkan sisa hasil usaha dan dapat memberikan kontribusi yang lebih banyak lagi.

\section{REFERENSI}

Dinas Perdagangan, Koperasi dan UKM Kota Pekalongan. 2021. “Perubahan Ketiga Rencana Strategis Dinas Perdagangan, Koperasi dan UKM Tahun 2016-2021."

https://dindagkop.pekalongankota.go.id//upload/file/file_20200629025 458.pdf

Efriyenti, Dian. 2018. "Pengaruh Perputaran Kas, Perputaran Piutang, dan Perputaran Modal Kerja Terhadap Rentabilitas pada PT Pelayaran Sinar Mandiri Sejahtera Kota Batam." Jurnal Akrab Juara 3 (3): 1-15.

Gunawan, M.N. 2019. "Pengaruh Tingkat Perputaran Kas, Perputaran Persediaan, Perputaran Piutang Terhadap Rentabilitas Ekonomi." Skripsi, STIE Ekuitas Bandung, Jawa Barat. 
Ibrahim, C. 2011. "Pengaruh Efektivitas Perputaran Piutang dan Perputaran Kas Terhadap Rentabilitas Ekonomi pada Koperasi Karyawan PT. Djarum Kudus." Jurnal Sosial dan Budaya Vol. IV: 150-158.

Kementerian Koperasi dan UKM Republik Indonesia. 2016-2020. “Rekapitulasi Data Koperasi per 31 Desember 2016-2020." Kemenkopukm.go.id https://kemenkopukm.go.id/datakoperasi/?RzHypWZLyjIoudYqhPPZGwFGnx1f0oWIdd6J0VUo5dTp6rV e6l

Kementerian Koperasi dan UKM Republik Indonesia. 2020. "Perlindungan Sosial dan Stimulus Ekonomi Menghadapi Dampak Covid-19." Kemenkopukm.go.id

https:// www.kemenkopukm.go.id/read/perlindungan-sosial-danstimulus-ekonomi-menghadapi-dampak-covid-19

Kementerian Koperasi dan Usaha Kecil dan Menengah Republik Indonesia. 2016. "Pedoman Penilaian Kesehatan Koperasi Simpan Pinjam dan Unit Simpan Pinjam Koperasi No: 06/Per/Dep.6/IV/2016." Sumbarprov.go.id https:/ / sumbarprov.go.id/images/1482118726-

Perdep06_2016_Penilaian_Kesehatan_KSP.pdf

Kementerian PPN/ Bappenas. 2020. Laporan Perkembangan Ekonomi Indonesia dan $\begin{array}{llll}\text { Dunia } & \text { Triwulan } & 2019 . & \text { Jakarta. }\end{array}$ https://www.bappenas.go.id/files/2715/8529/3891/Laporan_Perkemba ngan_Ekonomi_Indonesia_dan_Dunia_Triwulan_IV_2019.pdf.pdf

Kementerian PPN/Bappenas. 2020. "Sistem Ekonomi". Bappenas.go.id https://www.bappenas.go.id/files/2113/6082/9893/sistem-ekonomi_20081123060340_1001_0.pdf

Kementerian PPN/Bappenas. 2020. Laporan Perkembangan Ekonomi Indonesia dan Dunia Triwulan IV Tahun 2020. Jakarta. https://www.bappenas.go.id/files/5016/1759/6871/Laporan_Perkemba ngan_Ekonomi_Indonesia_dan_Dunia_Triwulan_IV_2020.pdf.pdf

Peraturan Pemerintah Republik Indonesia N0. 7 Tahun 2021 tentang Kemudahan, Perlindungan, dan Pemberdayaan Koperasi dan Usaha Mikro, Kecil, dan Menengah, https://jdih.setkab.go.id/PUUdoc/176384/PP_Nomor_7_Tahun_2021.pd $\mathrm{f}$

Presiden Republik Indonesia. 2020. “Serangkaian Stimulus dan Insentif bagi Masyarakat untuk Pertahankan Daya Beli." Presidenri.go.id https:/ / www.presidenri.go.id/siaran-pers/ serangkaian-stimulus-daninsentif-bagi-masyarakat-untuk-pertahankan-daya-beli/

Utami, A.T. 2020. “Pengaruh Perputaran Kas dan Perputaran Piutang Terhadap Rentabilitas Ekonomi pada Koperasi Finance di Bursa Efek Indonesia." Skripsi, Universitas Putera Batam. 